\title{
Kimura Disease of the Epiglottis: A Case Report and Review of Literature
}

\author{
Tetsurou Yamamoto $\cdot$ Sachiko Minamiguchi $\cdot$ \\ Yoshiki Watanabe $\cdot$ Jun Tsuji $\cdot$ Ryo Asato $\cdot$ \\ Toshiaki Manabe $\cdot$ Hironori Haga
}

Received: 20 June 2013/Accepted: 24 July 2013/Published online: 2 August 2013

(C) Springer Science+Business Media New York 2013

\begin{abstract}
Kimura disease (KD) affecting an unusual site is a diagnostic challenge. We report herein the case of a 62-yearold Japanese woman who presented with swelling of the epiglottis, resulting in airway narrowing. Microscopically, biopsied and resected specimens both revealed lymphoid proliferation of a reactive immunophenotype, accompanied by vascular proliferation, eosinophilic infiltration, and stromal sclerosis. Adjunctive immunohistochemistry with immunoglobulin $\mathrm{E}$ in addition to laboratory and histological findings led us to seriously consider a diagnosis of $\mathrm{KD}$. The patient underwent surgical removal with postoperative steroid therapy and has no evidence of recurrence. Our experience suggests that $\mathrm{KD}$ is potentially fatal as well as showing difficulty in the histological diagnosis when occurring in the upper respiratory tract, such as the epiglottis. A literature review disclosed that our case is the 11th case so far reported in this location, and that KD of the epiglottis did not show any male preponderance, as seen in other places.
\end{abstract}

Keywords Kimura disease $\cdot$ Epiglottis $\cdot$ Respiratory tract

T. Yamamoto $(\bowtie)$

Department of Pathology, National Hospital Organization Kyoto

Medical Center, 1-1 Mukaihata-cho Fukakusa Fushimi-ku,

Kyoto-shi, Kyoto 612-8555, Japan

e-mail: tyamamot@kyotolan.hosp.go.jp

S. Minamiguchi $\cdot$ H. Haga

Department of Diagnostic Pathology, Kyoto University Hospital,

54 Shogoin Kawahara-cho Sakyo-ku, Kyoto-shi,

Kyoto 606-8507, Japan

Y. Watanabe

Department of Otolaryngology, Head and Neck Surgery,

Osaka Red Cross Hospital, 5-30 Fudegasaki-cho Tennouji-ku,

Osaka-shi, Osaka 543-8555, Japan

\section{Introduction}

Kimura disease $(\mathrm{KD})$ is a rare chronic inflammatory disorder of unknown etiology, and usually presents as a subcutaneous mass in the head and neck region or the major salivary glands of young to middle-aged Asian men. It is often associated with regional lymphadenopathy. Elevated serum immunoglobulin $\mathrm{E}$ (IgE) and peripheral blood eosinophilia are also common. The histology of the lesion is characterized by dense lymphoid infiltrates containing prominent germinal centers, eosinophilic infiltrates, proliferation of postcapillary venules, and sclerosis. Recently, we have experienced KD occurring in the epiglottis with symptoms of slight dysphonia and dysphagia. A literature review showed that involvement of the epiglottis is rare, and only 10 cases of KD centered around the epiglottis were found. Here, we report an additional case and briefly review KD involving the upper respiratory tract. Lastly, we would like to stress that its unusual location may cause some difficulty in making a diagnosis histologically and clinically, and that it could be potentially fatal if left untreated.

\section{J. Tsuji}

Department of Otolaryngology, National Hospital Organization

Kyoto Medical Center, 1-1 Mukaihata-cho Fukakusa

Fushimi-ku, Kyoto-shi, Kyoto 612-8555, Japan

\section{R. Asato}

Department of Head and Neck Surgery, National Hospital

Organization Kyoto Medical Center, 1-1 Mukaihata-cho

Fukakusa Fushimi-ku, Kyoto-shi, Kyoto 612-8555, Japan

T. Manabe

Research Institute, Shiga Medical Center for Adults,

5-4-30 Moriyama, Moriyama-shi, Shiga 524-8524, Japan 


\section{Clinical Summary}

A 62-year-old Japanese woman, with a 3-month history of slight dysphonia and dysphagia, was found to have swelling of the epiglottis and anterior aspect of the right aryepiglottic fold with a smooth mucosal surface (Fig. 1). The tumor was $2.7 \times 2.0 \times 1.7 \mathrm{~cm}$. Laboratory investigations showed elevated serum IgE at $467 \mathrm{IU} / 1$ (normal range $<100 \mathrm{IU} / \mathrm{l}$ ) and peripheral eosinophil count of $7.4 \%$, that was slightly increasing (normal range 1-6\%). Soluble interleukin-2 receptor at $386 \mathrm{U} / \mathrm{ml}$ was within the normal range (122-496 U/ml). Computed tomography (CT) demonstrated a thickening of the epiglottis and the right aryepiglottic fold (Fig. 2a), and multiple cervical lymph node enlargement, each measuring up to $1 \mathrm{~cm}$ across (Fig. 2b). T1- and T2-weighted magnetic resonance imaging (MRI) depicted a homogenously hyperintense mass in the epiglottis and the right aryepiglottic fold (Fig. 2c, d). Malignancy, including lymphoma or carcinoma, was clinically suspected. Out of fear of airway obstruction, a tracheotomy was performed in our hospital with a biopsy of the lesion. The diagnosis of KD was considered based on the histological and laboratory findings, but initially hesitated because of its rarity in this location and the progressive clinical course. Under a possible diagnosis of $\mathrm{KD}$, we performed a wide resection for more precise evaluation and the diagnosis was confirmed. The patient has been on low dose corticosteroid for 32 months and remains free of recurrence.

\section{Pathological Findings}

Histologically, the first biopsy specimen showed a nonspecific chronic inflammatory change, except for mildly

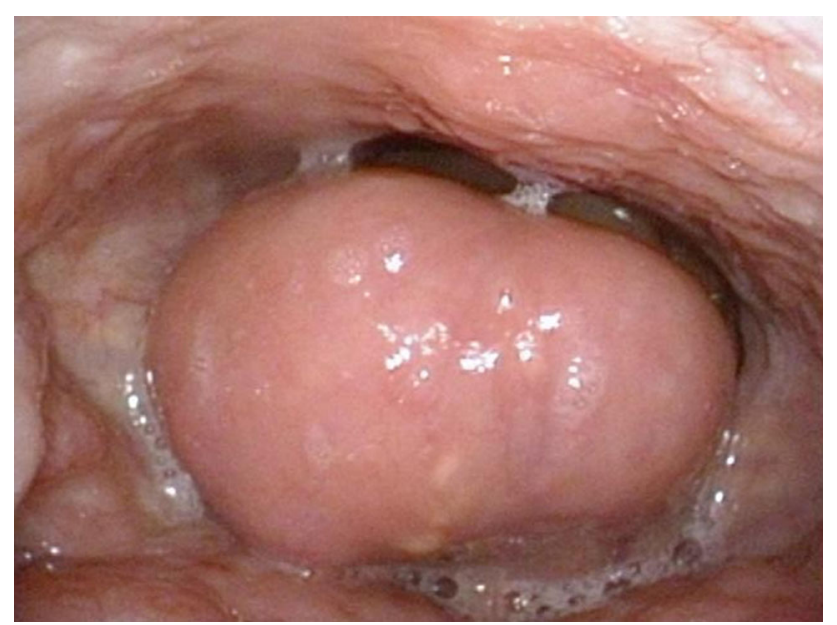

Fig. 1 Endoscopic view showing a mass-like swelling of the epiglottis about to obstruct the airway increased eosinophils. The second resected specimen was essentially similar but demonstrated vaguely nodular dense lymphoid aggregates with formation of follicles and germinal centers beneath the intact stratified squamous epithelium of the epiglottis, accompanied by vascular proliferation and numerous eosinophilic infiltrates within and around the lymphoid follicles, as well as stromal sclerosis (Figs. 3, 4, 5). CD138-positive plasma cells and CD117-positive mast cells were also intermingled. In some germinal centers, proteinaceous deposits could be observed (Fig. 6). Proliferating blood vessels were lined by swollen but conventional endothelium, without an epithelioid cell appearance. Immunohistochemical examination with $\operatorname{IgE}$ revealed characteristic reticular staining in germinal centers, identical to the distribution of follicular dendritic cells (Fig. 7). The immunophenotypical findings of lymphoid proliferation supported the reactive nature. These clinical and histological findings were considered compatible with $\mathrm{KD}$, despite the unconventionality of the site involved.

\section{Discussion}

Kimura disease is endemic in Asia, and therefore many cases have been collected and reviewed in Asian countries [1-3], while it occurs only infrequently in non-Asian populations [4]. In general, KD tends to affect young adults, with patient age ranging from 1 to 72 years, with a mean age of 32.8 years, and shows a striking male predilection ( $\mathrm{M}: \mathrm{F}=5: 1)$. A subcutaneous mass in the head and neck region or a mass in the major salivary glands is the usual presentation, often being associated with regional lymphadenopathy [1-6]. Occasionally, lymph node enlargement is the only manifestation. The treatment for $\mathrm{KD}$ includes surgical excision, steroid therapy, and radiation. Although recurrences are common, the disease usually follows a benign clinical course. Other sites such as the oral cavity, axilla, groin, limbs, and trunk have also been described, but the involvement of the respiratory tract is rare. To our knowledge, 10 cases of KD centered around the epiglottis have appeared in the English and Japanese literature [7-16]. Our case provides an additional example (Table 1).

Among 10 cases that appeared in the literature as epiglottic KDs and our own case, there were six males and five females, thereby showing no apparent male predilection in these cases. Their ages ranged from 12 to 72 years, with a mean age of 39.2 years, which was in line with cases involving the usual sites. The symptoms were mostly related to airway narrowing, although two patients were asymptomatic. Because of symptoms related to respiratory problems, patients seem to have consulted doctors earlier, and eight cases were treated by surgery, five of whom 

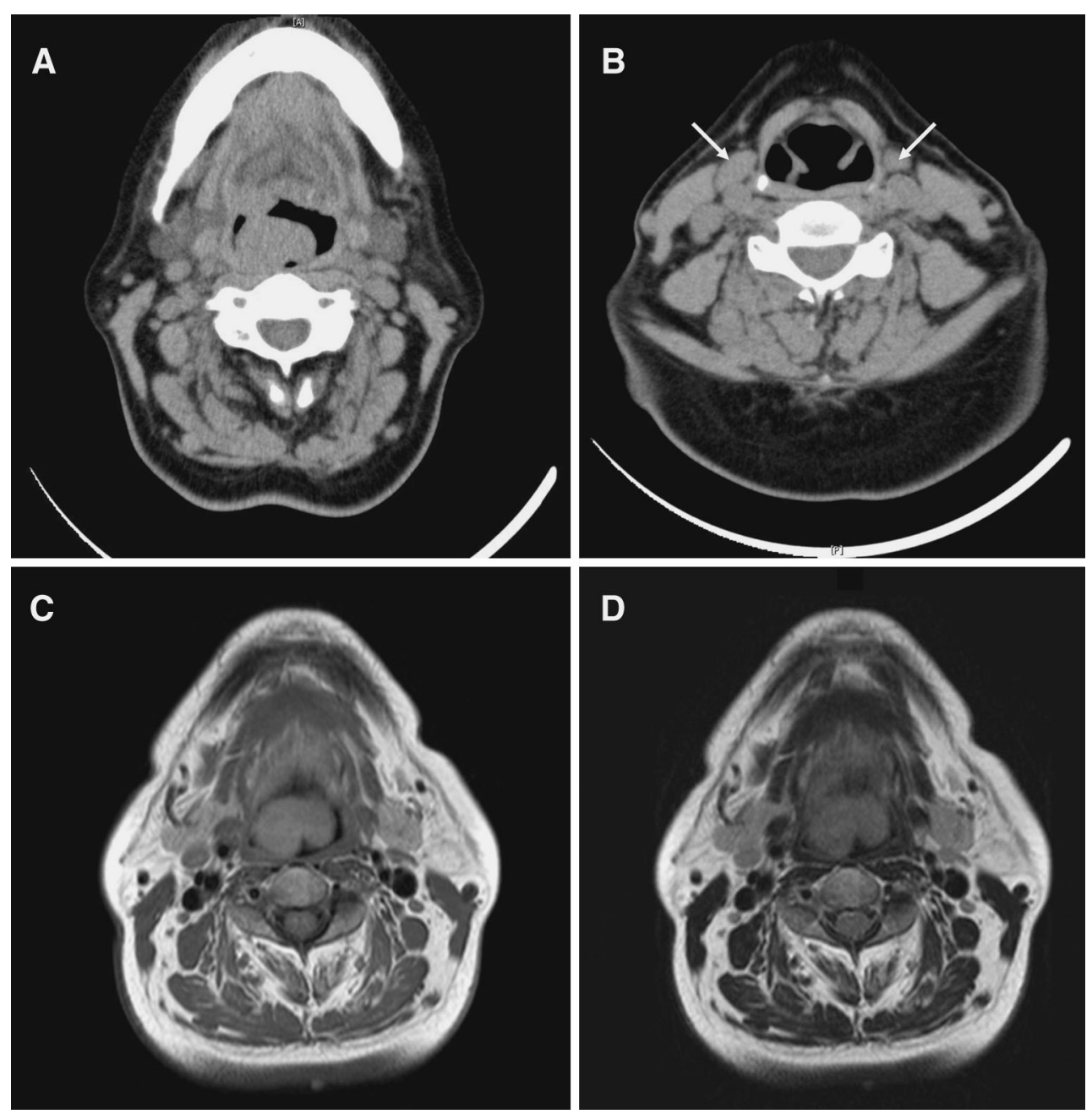

Fig. 2 CT showing a mass-like thickening of the epiglottis (a), and multiple cervical lymph node enlargement (b). T1-weighted (c) and T2weighted (d) MRI displaying a homogenously hyperintense mass in the epiglottis

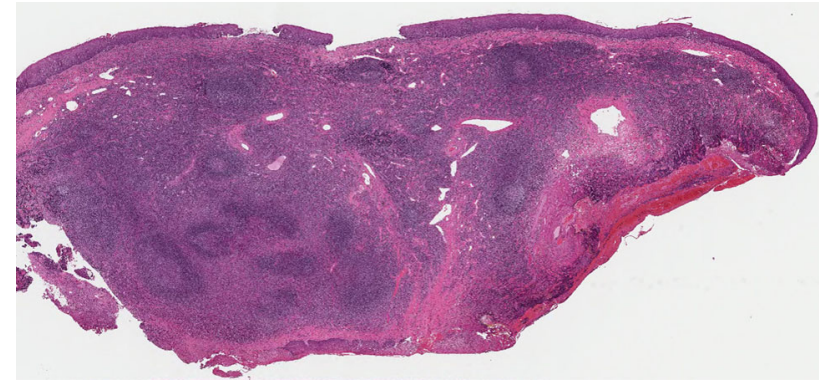

Fig. 3 Resected specimen showing submucosal nodular lymphoid aggregates containing follicles and germinal centers with sclerotic stroma (hematoxylin-eosin, original magnification $\times 20$ )

became free of disease, one recurred but was free of disease after additional steroid therapy, one persisted, and one was lost follow-up. In contrast, two out of three patients treated by oral steroid alone or with other medications suffered persistent disease. In all cases, none of the patients died of the disease after treatment, but if untreated it may be fatal because of its location. Therefore, we believe that treatment is necessary and that the surgery seems most effective, and steroids are also beneficial to some extent.

Histology of KD may vary among cases and among locations in the same case. It characteristically consists of cellular (increased eosinophils and follicular hyperplasia), fibrocollagenous, and vascular (proliferation of the postcapillary venule) components. Other features include eosinophilic microabscesses, eosinophilic folliculolysis, germinal center (GC) necrosis, proteinaceous deposits in GC, polykaryocytes of the Warthin-Finkeldey type within GC, and $\mathrm{IgE}$ reticular staining in GC $[1,2,4]$. Findings may be basically non-specific and may cause some difficulty in making a histological diagnosis, particularly when the tissue sample is small, such as when obtained by biopsy. Histological differential diagnosis of KD may include angiolymphoid hyperplasia with eosinophilia (ALHE), Hodgkin lymphoma (HL), angioimmunoblastic $\mathrm{T}$ cell lymphoma (AITL), Langerhans cell histiocytosis (LCH), florid follicular 


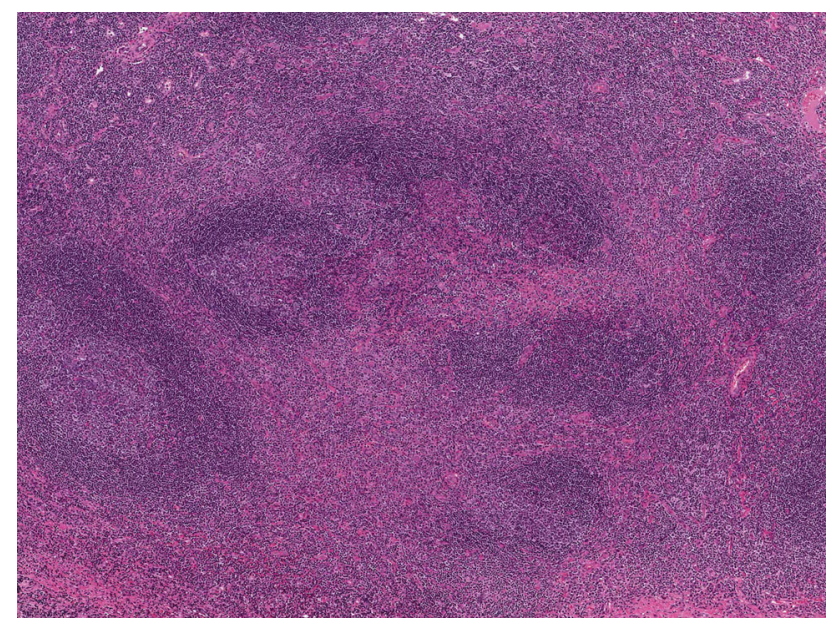

Fig. 4 Increased vessels and inflammatory infiltrates within and around the lymphoid follicles (hematoxylin-eosin, original magnification $\times 50$ )

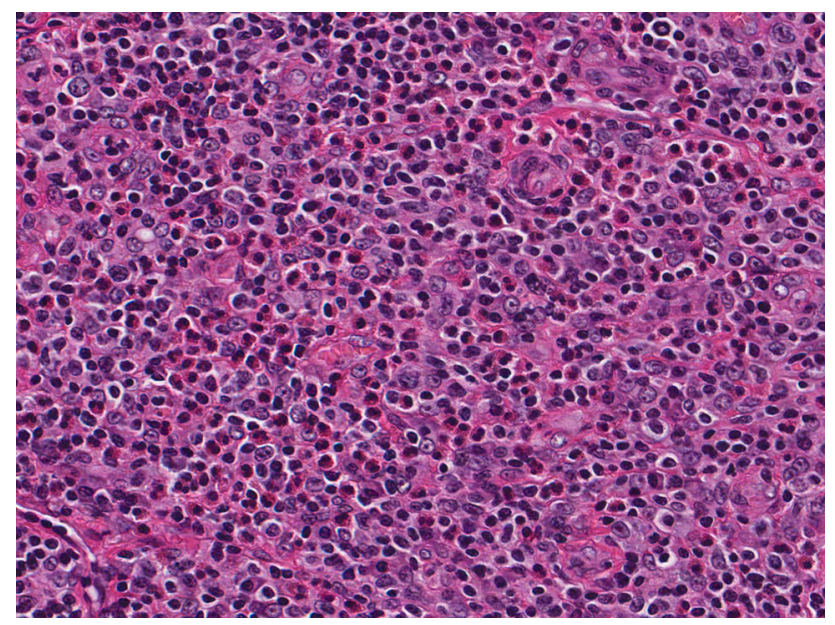

Fig. 5 Increased vessels and prominent eosinophils (hematoxylineosin, original magnification $\times 400$ )

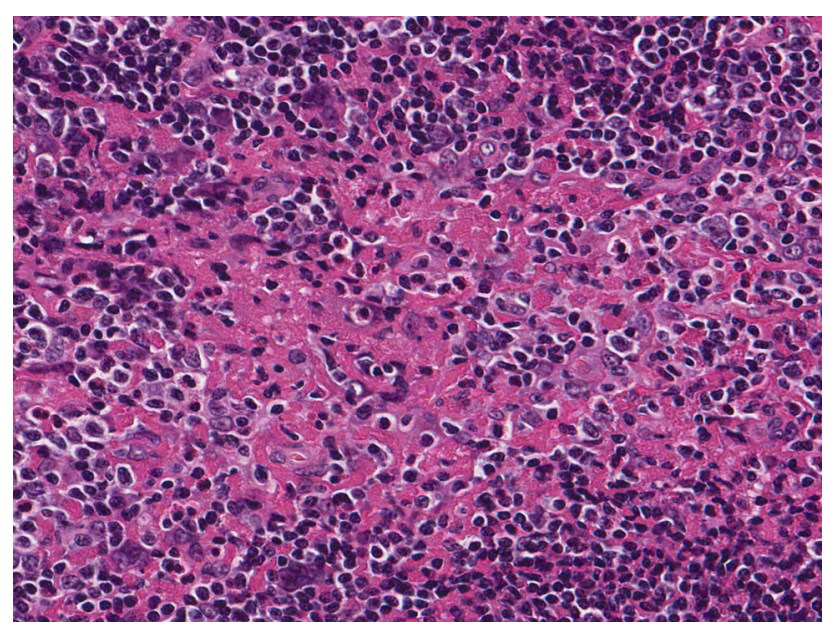

Fig. 6 Proteinaceous deposits in a germinal center (hematoxylineosin, original magnification $\times 400$ )

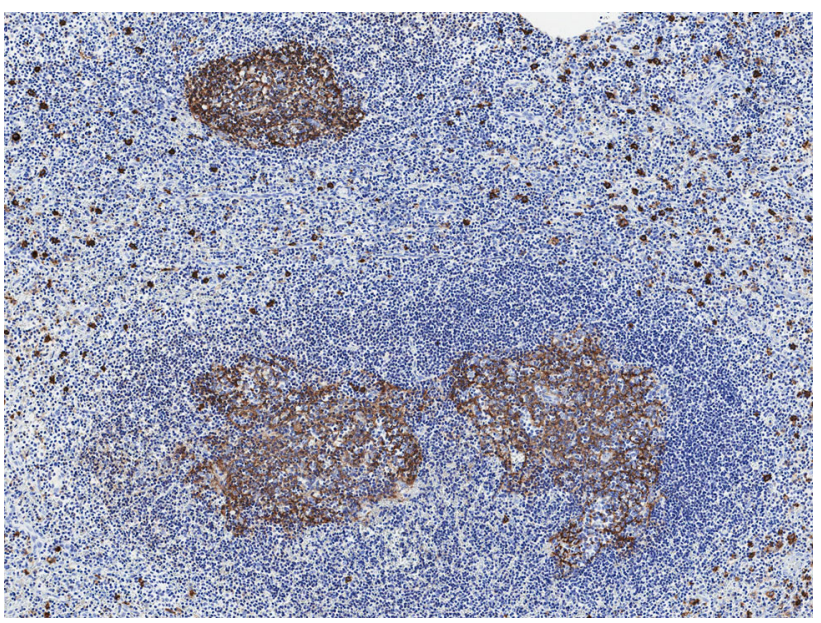

Fig. 7 Germinal centers showing reticular staining of $\operatorname{IgE}$ and surrounding $\mathrm{IgE}$-positive mast cells (original magnification $\times 100$ )

hyperplasia, Castleman disease (CD), dermatopathic lymphadenopathy (DL), sinonasal eosinophilic angiocentric fibrosis (EAF), drug reaction, parasitic reaction and others. Although KD has been confused and sometimes used synonymously with ALHE, it is now thought that these are entirely different entities [2,5]. KD differs from ALHE in that the lymphoid component eclipses the minor vascular component and lacks the epithelioid endothelial cells that are the morphologic hallmark of ALHE. KD can be distinguished from HL by the absence of Hodgkin/Reed-Sternberg cells and its variants, and from AITL by neoplastic clear cells. The absence of proliferative Langerhans cells that have distinctive cytologic features can exclude a diagnosis of LCH. Florid follicular hyperplasia shows proliferation of the postcapillary venule, proteinaceous deposits in GC, polykaryocytes, but lacks eosinophilia. The follicle in $\mathrm{CD}$ of the hyaline-vascular variant has atrophic germinal centers and tight concentric layering of the mantle zone, and a sclerotic blood vessel radially penetrates the germinal center, resulting in a "lollipop lesion". CD of the plasma cell variant is characterized by diffuse plasma cell proliferation in the interfollicular area. Both variants of CD also lack eosinophilia. DL is distinguished by deposits of hemosiderin, melanin, and lipids, and KD usually does not show paracortical expansion by nodular proliferation of interdigitating dendritic cells and Langerhans cells, characteristics of DL. EAF lacks dense lymphoid aggregates with prominent germinal centers, and shows characteristic angiocentric whorled fibrosis. A careful clinical correlation helps in distinguishing KD from drug and parasitic reactions. Immunohistochemical analysis is also required to confirm the diagnosis.

The pathogenesis of $\mathrm{KD}$ remains unclear, but an immunologically-mediated mechanism has been suggested, based on the laboratory and histological findings. We suppose that air-borne and dietary agents may have a 
Table 1 Reported cases of Kimura disease around the epiglottis

\begin{tabular}{|c|c|c|c|c|c|c|c|}
\hline $\begin{array}{l}\text { Case } \\
\text { [Ref.] }\end{array}$ & $\begin{array}{l}\text { Age/Sex } \\
\text { Race }\end{array}$ & Site & Symptoms & $\begin{array}{l}\text { Blood } \\
\text { eosinophils (\%) }\end{array}$ & $\begin{array}{l}\text { Serum } \\
\operatorname{IgE}(\mathrm{IU} / \mathrm{l})\end{array}$ & Treatment & $\begin{array}{l}\text { FU } \\
\text { (months) }\end{array}$ \\
\hline $1[7]$ & $\begin{array}{l}\text { 61/F } \\
\text { Japanese }\end{array}$ & $\begin{array}{l}\text { Epiglottis } \\
\text { Rt. preauricular mass }\end{array}$ & $\begin{array}{l}\text { Abnormal feeling } \\
\text { in the larynx }\end{array}$ & 18 & 595 & Oral steroids & PD \\
\hline $2[8]$ & $\begin{array}{l}\text { 15/M } \\
\text { Korean }\end{array}$ & $\begin{array}{l}\text { Epiglottis } \\
\text { Cervical LN }\end{array}$ & $\begin{array}{l}\text { Stridor during sleeping } \\
\text { and dysphagia }\end{array}$ & 17.5 & 375 & $\begin{array}{l}\text { Surgery } \\
\text { Oral steroids }\end{array}$ & $\mathrm{FD}(1)$ \\
\hline $3[9]$ & $\begin{array}{l}\text { 14/M } \\
\text { Japanese }\end{array}$ & $\begin{array}{l}\text { Bi. false vocal cords } \\
\text { Cervical LN }\end{array}$ & Sleep apnea & 16.4 & 1260 & $\begin{array}{l}\text { Surgery } \\
\text { Oral steroids } \\
\text { Pranlukast }\end{array}$ & FD \\
\hline $4[10]$ & $\begin{array}{l}72 / \mathrm{F} \\
\text { Japanese }\end{array}$ & Epiglottis & $\begin{array}{l}\text { Abnormal feeling } \\
\text { in the larynx }\end{array}$ & 9.7 & 797 & $\begin{array}{l}\text { Oral steroids } \\
\text { Herbal medicine } \\
\text { "Saibokutoh" }\end{array}$ & FD (31) \\
\hline $5[11]$ & $\begin{array}{l}\text { 41/M } \\
\text { Turkish }\end{array}$ & Paraglottic space & Voice hoarsening & NA & NA & Surgery & $\mathrm{FD}(6)$ \\
\hline $6[12]$ & $\begin{array}{l}\text { 21/M } \\
\text { Japanese }\end{array}$ & $\begin{array}{l}\text { Epiglottic vallecula } \\
\text { Bi. parotid glands } \\
\text { Cervical LN }\end{array}$ & NA & 59.5 & 652 & $\begin{array}{l}\text { Surgery } \\
\text { Oral steroids }\end{array}$ & Rec. (24) \\
\hline $7[13]$ & $\begin{array}{l}\text { 37/F } \\
\text { Arabic }\end{array}$ & Epiglottis & $\begin{array}{l}\text { Difficulty in breathing } \\
\text { and swallowing }\end{array}$ & 9 & NA & Surgery & Lost \\
\hline $8[14]$ & $\begin{array}{l}\text { 45/M } \\
\text { Japanese }\end{array}$ & $\begin{array}{l}\text { Epiglottis } \\
\text { Lt. parotid gland } \\
\text { Lt. lacrymal gland }\end{array}$ & Asymptomatic & 32.9 & NA & Tranilast & PD (24) \\
\hline $9[15]$ & $\begin{array}{l}52 / \mathrm{F} \\
\text { Japanese }\end{array}$ & Epiglottis & $\begin{array}{l}\text { Sensation of a foreign } \\
\text { body in the pharynx }\end{array}$ & 12.5 & NA & Surgery & PD (24) \\
\hline $10[16]$ & $\begin{array}{l}\text { 12/M } \\
\text { Singaporean }\end{array}$ & $\begin{array}{l}\text { Epiglottis } \\
\text { Cervical LN }\end{array}$ & Asymptomatic & 11 & NA & Surgery & FD \\
\hline 11 [Our case] & $\begin{array}{l}\text { 62/F } \\
\text { Japanese }\end{array}$ & $\begin{array}{l}\text { Epiglottis } \\
\text { Cervical LN }\end{array}$ & Dysphonia and dysphagia & 7.4 & 467 & $\begin{array}{l}\text { Surgery } \\
\text { Oral steroids }\end{array}$ & FD (32) \\
\hline
\end{tabular}

$F D$ free of disease, $F U$ follow-up, $L N$ lymph node, $N A$ not available, $P D$ persistent disease, $R e c$. recurrence

higher proportion among the etiological factors, because of the absence of gender predilection and the presence in the vicinity of the throat.

In summary, we report a case of $\mathrm{KD}$ involving the epiglottis. A review of the literature disclosed that it is rare and that males and females are equally affected in comparison with general male predominance. Rarity in this location may hinder a pathological diagnosis, so it is important to consider and include the possibility of KD in the differential diagnosis whenever chronic inflammatory conditions with germinal centers are seen with increased eosinophils in particular.

Conflict of interest The authors report no conflicts of interest and funding disclosures.

\section{References}

1. Hui PK, Chan JK, Ng CS, Kung IT, Gwi E. Lymphadenopathy of Kimura's disease. Am J Surg Pathol. 1989;13(3):177-86.
2. Urabe A, Tsuneyoshi M, Enjoji M. Epithelioid hemangioma versus Kimura's disease. A comparative clinicopathologic study. Am J Surg Pathol. 1987;11(10):758-66.

3. Xu X, Fu J, Fang Y, Liang L. Kimura disease in children: a case report and a summary of the literature in Chinese. J Pediatr Hematol Oncol. 2011;33(4):306-11.

4. Chen H, Thompson LD, Aguilera NS, Abbondanzo SL. Kimura disease: a clinicopathologic study of 21 cases. Am J Surg Pathol. 2004;28(4):505-13.

5. Helander SD, Peters MS, Kuo TT, Su WP. Kimura's disease and angiolymphoid hyperplasia with eosinophilia: new observations from immunohistochemical studies of lymphocyte markers, endothelial antigens, and granulocyte proteins. J Cutan Pathol. 1995;22(4):319-26.

6. Zhang JZ, Zhang CG, Chen JM. Thirty-five cases of Kimura's disease (eosinophilic lymphogranuloma). $\mathrm{Br} \quad \mathrm{J}$ Dermatol. 1998;139(3):542-3.

7. Takahashi N, Kawamoto K, Takeuchi Y. Eosinophilic granuloma of the soft tissue (Kimura's disease) on the epiglottis. Practica Otologica. 1995;41(2):157-61.

8. Cho MS, Kim ES, Kim HJ, Yang WI. Kimura's disease of the epiglottis. Histopathology. 1997;30(6):592-4.

9. Okami K, Onuki J, Sakai A, Tanaka R, Hagino H, Takahashi M. Sleep apnea due to Kimura's disease of the larynx. Report of a case. ORL J Otorhinolaryngol Relat Spec. 2003;65(4):242-4. 
10. Tasei A, Tsutsumi T, Shimoide Y. A rare case of Kimura's disease of the epiglottis treated with herbal medicine "Saibokutoh". Practica Otologica. 2003;96(11):999-1004.

11. Akyol U, Tatar EC, Sungur AA. Kimura's disease in paraglottic space. Otolaryngol Head Neck Surg. 2006;135(6):989-90.

12. Iwai H, Nakae K, Ikeda K, Ogura M, Miyamoto M, Omae M, Kaneko T, Yamashita T. Kimura disease: diagnosis and prognostic factors. Otolaryngol Head Neck Surg. 2007;37(2):306-11.

13. Badr A, Abdul-Haleem A, Carlsen E. Kimura disease of the epiglottis. Head Neck Pathol. 2008;2(4):328-32 [Epub 2008 Aug 22].
14. Kamitani T, Taki M, Matsui M. A case of Kimura's disease of the parotid gland, eyelid and epiglottis. Jibi Inkoka, Tokeibu Geka. 2008;80(10):737-41.

15. Kawata R, Yoshimura K, Ichihara T, Takenaka H, Tsuji M. Kimura's disease of the epiglottis: resection by a lateral pharyngotomy approach. Otolaryngol Head Neck Surg. 2010;142(1):148-9 [Epub 2009 Sept 2].

16. Lim KH, Ang AHC, Tan HKK. Kimura disease of the epiglottis: an unusual cause of upper airway obstruction. Int $\mathbf{J}$ Pediatr Otorhinolaryngol Extra. 2012;2(1):18-20. 